\title{
AXILLOFEMORAL FISTULA FOR HEMODIALYSIS ACCESS
}

\author{
Petr Utikal ${ }^{\mathrm{a}}$, Petr Bachleda ${ }^{\mathrm{a}}$, Martin Koecher ${ }^{\mathrm{b}}$, Petr Drac ${ }^{\mathrm{a}}$, Marie Cerna ${ }^{\mathrm{b}}$ \\ a $2^{\text {nd }}$ Clinic of Surgery, University Hospital Olomouc, Czech Republic \\ ${ }^{b}$ Clinic of Radiology, University Hospital Olomouc \\ e-mail:petr.utikal@fnol.cz
}

Received: April 12, 2006; Accepted: May 6, 2006

Key words: Hemodialysis/Vascular access/Arteriovenous fistula/ePTFE prosthesis/Axillary artery/Femoral vein

The authors describe the technique of axillo-femoral arteriovenous prosthesis interposition and evaluate their experience with this non-conventional access for hemodialysis.

\section{INTRODUCTION}

The main current problem of hemodialysis - permanent vascular access creation - is that of a continuously increasing number of difficult patients with primarily unsuitable or secondarily exhausted vessels. That is the reason not only for prosthesis use, but also for its nonconventional connection and placement ${ }^{1-7}$.

Axillo-femoral arteriovenous prosthesis interposition - fistula (AF AVF) is one of such less typical access creations $^{7,8}$.

\section{METHODS}

Candidates for AF AVF are patients with problematic superior vena cava outflow site - completely occluded or severely stenosed superior vena cava (SVC), bilateral brachiocephalic (BCV), jugular (JV) and subclavian (SV) veins, in case all interventional radiological options for its correction have been unsuccessful and surgical repair has been impossible (Fig. 1).

DIASTAT (GORE) ePTFE stretch prosthesis conically shaped (from 4 to $7 \mathrm{~mm}$ ) of $40 \mathrm{~cm}$ length with cannulation segment of $25 \mathrm{~cm}$ is the basis for AF AVF. It is mostly necessary to extend the DIASTAT prosthesis on both ends to get the required overall length. ePTFE stretch ringed prosthesis of adequate diameter $(6 \mathrm{~mm}$ on the inflow site, $8 \mathrm{~mm}$ on the outflow site) is useful for this. The prosthesis is anastomosed (ePTFE 6.0 stitch) end to side to axillary artery proximally (exposed from subclavicular incision, inflow arterial anastomosis $6 \mathrm{~mm}$ in length) and distally to common femoral vein (exposed from groin incision, outflow venous anastomosis $18 \mathrm{~mm}$ of length) and using a tunneler it is subcutaneously placed (cannulating segment of the prosthesis lies on the ribs) laterally on the anterior body wall (Fig. 2, 3).

\section{PATIENTS}

During the past 5 years (2000-2004) we created 5 AF AVFs in 5 patients in whom the repair of SVC outflow site completely failed. All patients had long term dialysis and previous native and bridge ePTFE fistulas creations and subclavian or jugular catheters placed a number of times to overcome complications in previous upper arm access (Tab. 1). Before the decision on AF AVF, inferior vena cava ( using US doppler or phlebography) and the hemodynamic and coagulative state of the patient were evaluated. The procedure was performed under general anesthesia under common conditions for vascular surgery - antibiotic prophylaxis (wide spectrum, in three doses) and early thrombosis prevention (LMW heparin). Tensamin infusion $(2-10 \mu \mathrm{g} / \mathrm{kg} / \mathrm{min})$ was used to prevent postoperative hypotension.

\section{RESULTS}

There were no severe peroperative and early postoperative complications. All the fistulas were successfully used for dialysis with an acceptable rate of thrombotic complications. The thrombotic complication repairs contribute to excellent cumulative function. One patient with a functional graft died (Tab. 2-4).

\section{DISCUSSION}

The exhaustion of SVC outflow site is related to previous central vein cannulations, catheters implantation and central bridge fistulas creations with additional procedures for maintaining their passage during the time, with consequent venous fibrosis or occlusion ${ }^{9-13}$. Arteriovenous fistula (AVF) is the best permanent vascular access for hemodialysis. The native fistulas and bridge fistulas (using vascular prosthesis) located in the upper limb region with SVC outflow site are the best conventional access 


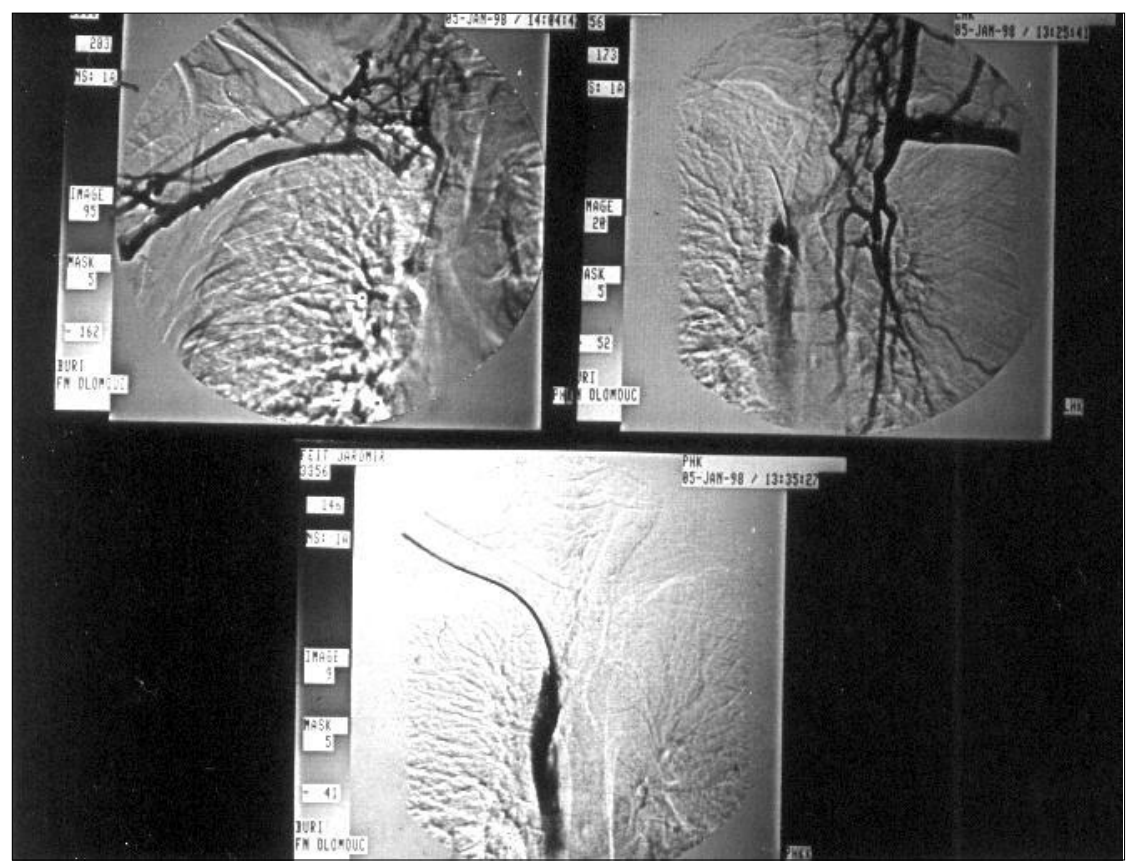

Fig. 1. Superior vena cava outflow site occlusion (bilateral brachiocephalic vein occlussion).

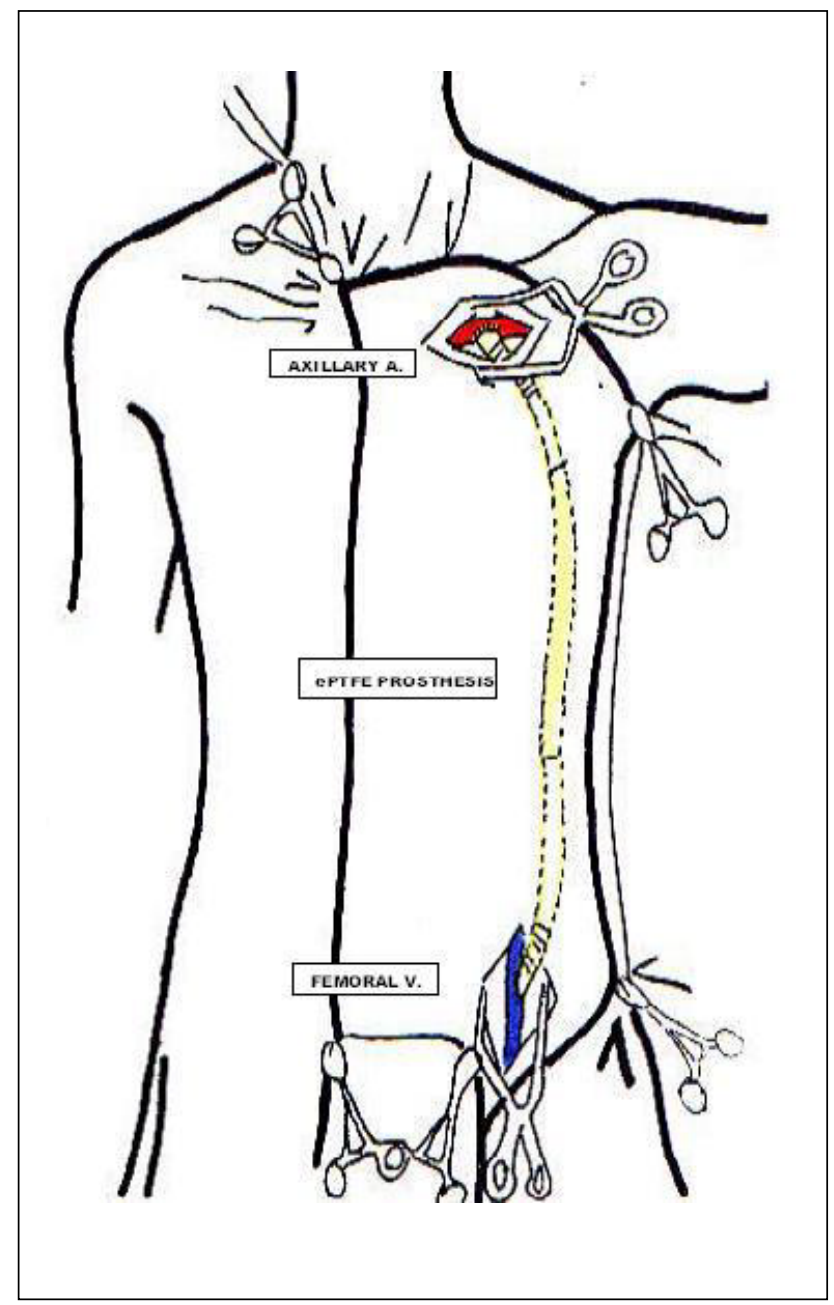

Fig. 2. Schema of AF AVF.

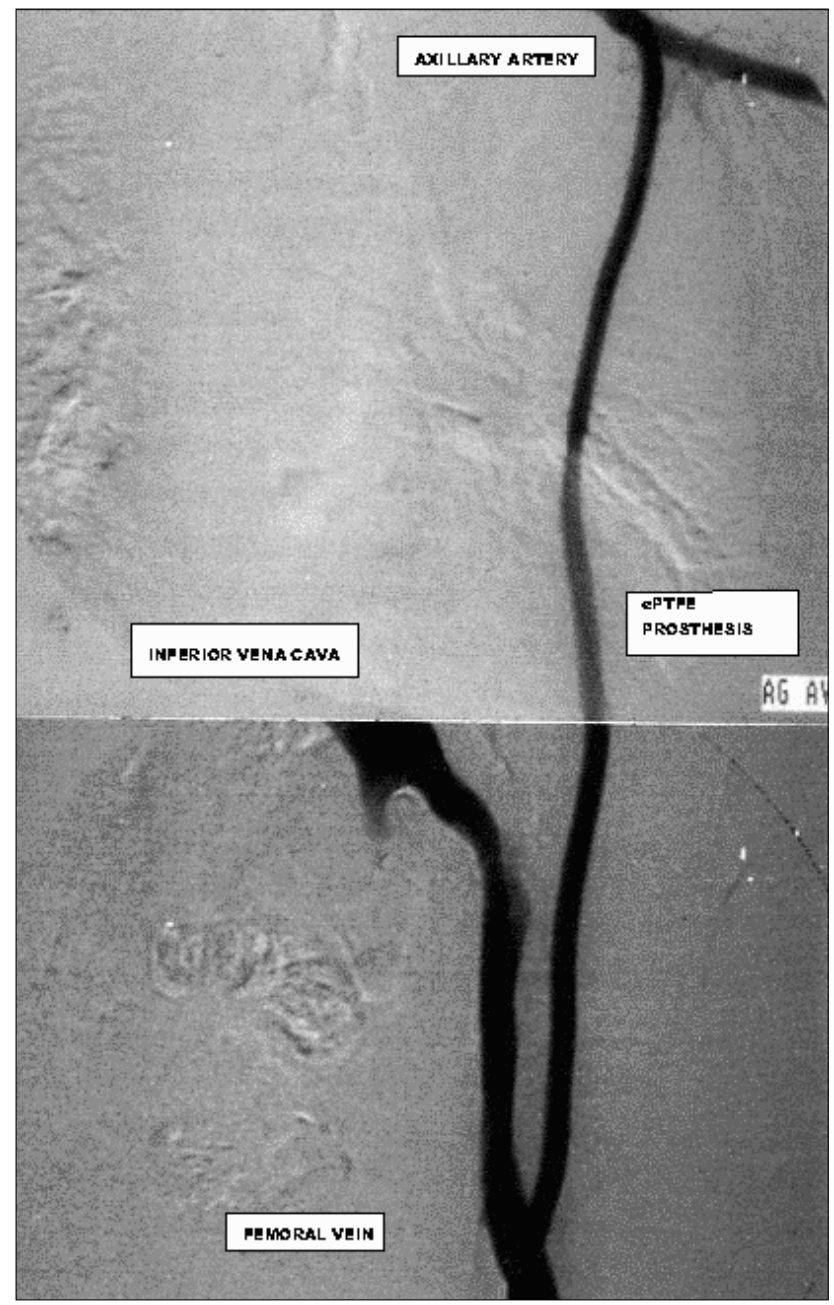

Fig. 3. Angiography of AF AVF. 
Table 1. Dates of the patient receiving AF AVF.

\begin{tabular}{|c|c|c|c|c|c|c|c|c|c|c|c|}
\hline \multirow{3}{*}{\multicolumn{2}{|c|}{ PATIENT }} & \multicolumn{5}{|c|}{ PREVIOUS ACCESSES } & \multirow{3}{*}{$\begin{array}{c}\text { SVC } \\
\text { OUTFLOW } \\
\text { SITE }\end{array}$} & \multicolumn{4}{|c|}{ AXILLO-FEMORAL GRAFT } \\
\hline & & \multirow{2}{*}{ PRIMARY } & \multirow{2}{*}{ NATIVE } & \multirow{2}{*}{ ePTFE } & \multicolumn{2}{|c|}{$\begin{array}{l}\text { CENTRAL } \\
\text { CATHETERS }\end{array}$} & & \multirow{2}{*}{$\begin{array}{l}\text { CREATION } \\
\text { DATE }\end{array}$} & \multicolumn{2}{|c|}{ FUNCTION } & \multirow{2}{*}{\begin{tabular}{|l} 
No of \\
REPAIR
\end{tabular}} \\
\hline & & & & & svc & $\mathrm{FV}$ & & & CURRENT & $\begin{array}{l}\text { DURATION } \\
\text { MONTHS }\end{array}$ & \\
\hline 1 & $\begin{array}{c}1 \\
* 1938\end{array}$ & 1993 & 4 & 1 & 4 & 2 & $\begin{array}{l}\text { SVC } \\
\text { occlusion }\end{array}$ & $9 / 00$ & + & 52 & 4 \\
\hline 2 & \begin{tabular}{|}
$\mid$ \\
$* 1947$
\end{tabular} & 1996 & 2 & 3 & 3 & 1 & $\begin{array}{l}\text { BCVV } \\
\text { occlusion }\end{array}$ & $3 / 01$ & - & $\begin{array}{c}\boldsymbol{t} \\
23\end{array}$ & 2 \\
\hline 3 & $\begin{array}{l}\prod_{* 1935} \\
*\end{array}$ & 1999 & 2 & 0 & 5 & 1 & $\begin{array}{l}\text { BCVV } \\
\text { occlusion }\end{array}$ & $4 / 01$ & + & 36 & 6 \\
\hline 4 & $\begin{array}{c}\mid \\
* 1952\end{array}$ & 1997 & 4 & 2 & 8 & - & $\begin{array}{l}\text { SV+JVv dx } \\
\text { occlusion } \\
\text { BCV sin } \\
\text { STENosis }\end{array}$ & $12 / 03$ & + & 16 & 3 \\
\hline 5 & $\begin{array}{c}1 \\
* 1941\end{array}$ & 2001 & 1 & 3 & 3 & - & $\begin{array}{l}\text { BCVV } \\
\text { STENosis }\end{array}$ & $10 / 04$ & + & 6 & 1 \\
\hline
\end{tabular}

creations $^{3,4,7,14-15}$. Central venous occlusion of the upper limbs (SVC outflow site) makes the AVF creation in this location impossible. Therefore we have to utilize all the interventional radiological methods for SVC outflow site repair before the decision on its unfitness. Surgical repairs in SVC central veins region are usually not possible due to extreme operating and complication rate risk ${ }^{16-19}$. Thorough preoperative vessel evaluation and the stable hemodynamic and coagulative condition of the patient are the basic prerequisites to prevent fistula failure ${ }^{7,20,21}$. Therefore the patients have to be evaluated thoroughly in connection with its creation, especially in the AF AVF type of fistula ${ }^{7,21}$. Patients with pathological findings are contraindicated for AF AVF. Prosthesis interposition between a high blood flow axillary artery and a femoral vein of large diameter provides excellent flow for high flux dialysis. Prosthesis length gives a wide choice of sites for cannulations and increases potential viability of the prosthesis. The prosthesis placement laterally on the anterior body wall is cosmetically acceptable for patients. The thick, less sensitive and infection resistant skin in this region enables easy and well tolerated cannulation. The construction of the DIASTAT prosthesis cannulating segment allows us to stop puncture bleeding using a small brief compression (Fig. 4).Therefore this type of prosthesis is an advantage in places problematic in terms of prosthesis compression such as the anterior body wall. Owing to this construction, cannulation is possible immediately after fistula creation when necessary. The stretch type of e PTFE prosthesis reduces the risk of intimal hyperplasia stenotic complications, especialy on the venous outflow site $^{6,22-25}$. The main disadvantage of AF AVF is the prosthesis length increasing the risk of thrombosis. Therefore care should be taken to avoid periods of low blood pres-

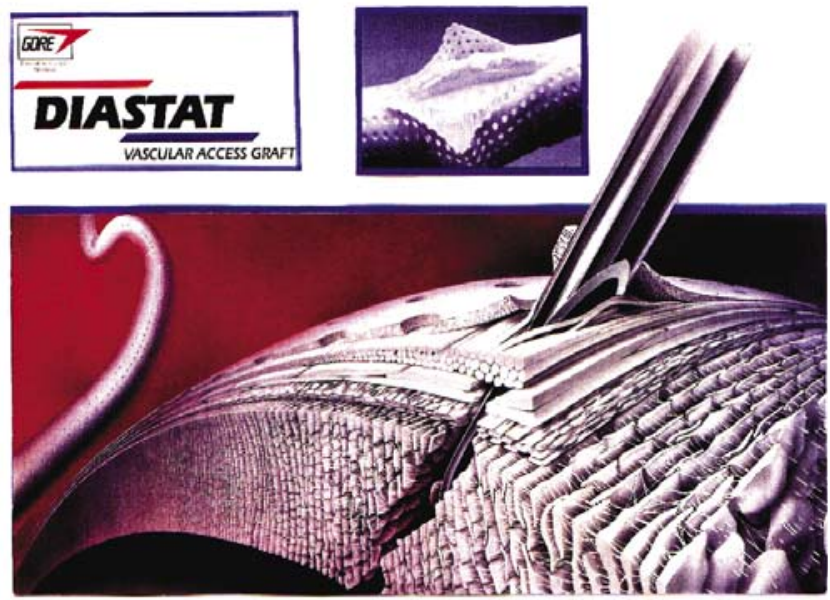

Fig. 4. Schema of Diastat ePTFE prosthesis (GORE) cannulating segment.

sure in patients with these fistulas7. Another disadvantage is the outflow anastomosis in the inguinal region, with the risk of prosthesis kinking and with high infection complication rate. In order to avoid these complications, outflow anastomosis creation on iliac vein from the suprainguinal access is possible. Combined approach seems to be the option for AF AVF thrombotic - stenotic complications solution. Surgical thrombectomy (using Fogarty baloon catheter) of ePTFE prosthesis is easy and interventional radiological anastomotic stenoses repair ( baloon angioplasty ) produces good results ${ }^{19,26-29}$. Only local anesthesia and one incision as repair accesss are needed. The use of Fogarty wire catheter and direct surgery are other options for stenoses repair. When the outflow site complications (iliac vein stenoses or occlusion) repair is not successful, 
Table 2. Complications of AF AVF.

\begin{tabular}{|c|c|}
\hline COMPLICATIONS & \\
\hline $\begin{array}{l}\text { PEROPERATIVE } \\
\text { NO }\end{array}$ & GRAFT THROMBOSIS \\
\hline $\begin{array}{l}\text { EARLY POSTOPERATIVE } \\
\text { NO CARDIAC FAILURE } \\
\text { INFECTION }\end{array}$ & $\begin{array}{l}16 \text { GRAFT THROMBOSIS } \\
\text { IN } 5 \text { FISTULAS }\end{array}$ \\
\hline $\begin{array}{l}1 \text { GRAFT THROMBOSIS } \\
1 \text { TUNNEL HEMATOMA }\end{array}$ & MEAN NUMBER 3.2 RANGE 1-6 \\
\hline $\begin{array}{l}\text { LATE } \\
\text { NO HYPERFUNCTION } \\
\text { PERIPHERY ISCHEMIA } \\
\text { CARDIAC FAILURE } \\
\text { VENOUS HYPERTENSION } \\
\text { SKIP LEASION } \\
\text { INFECTION }\end{array}$ & \begin{tabular}{l} 
CAUSES OF THROMBOSIS \\
HYPTENSION \\
HYPECOAGULATION \\
VENOUS ANASTOMOSIS STENOSIS \\
\multicolumn{1}{c}{ INTIMAL HYPERPLASIA } \\
GRAFT STENOSIS
\end{tabular} \\
\hline $\begin{array}{c}\text { FALS ANEURYSM } \\
1 \text { PERIGRAFT SEROMA }\end{array}$ & \\
\hline
\end{tabular}

cross over new outflow creation on the opposite femoral or iliac vein is possible. Longterm antiaggregant or anticoagulant therapy is recommended in case of repeated thrombotic complications ${ }^{7}$. There are AF AVF alternatives. Double-lumen tunneled cuffed catheter in inferior vena cava outflow region placement is an easy option, but not a more durable one ${ }^{30-31}$. Peritoneal dialysis may be another possibility ${ }^{32-33}$. Urgent kidney transplantation seems to be the option in some patients with missing vascular access for hemodialysis, especially in young patients ${ }^{34}$.

\section{CONCLUSION}

Axillary artery to common femoral vein ePTFE bridge fistula seems to be an excellent and durable hemodialysis access strategy with acceptable thrombosis and infection rate.

In the dialysis access algorithm it is recommended for patients with exhausted superior vena cava outflow site before resorting to lower limb fistulas or permanent venous catheter ${ }^{35}$.

\section{REFERENCES}

1. Haimov M. (1982) Vascular access for hemodialysis- New modifications for the difficult patients. Surgery 92, 109-110.

2. Raju S. (1987) PTFE grafts for hemodialysis access. Ann Surg 206, 666-667

3. Far PY, Schwab SJ.(1992) Vascular access:concepts for the 1990s. J Am Soc Nephrol 3, 1-11.

4. Bachleda P, Utíkal P, Köcher M, Zadražil J, Král V, Grossmanová T. (1996) Př́spěvek k zakládání arteriovenózních spojek k dialýze interpozicí ePTFE(GORETEX) protéz. Rozhl Chir 75, 26-30.

5. McCann RL. (1996) Axillary grafts for difficult hemodialysis access. J Vasc Surg 24, 457-462.

6. Utíkal P, Bachleda P, Sekanina Z (1998) Axiloaxilární kontralaterální arteriovenózní spojka k dialýze s interpozicí DIASTAT -GORE protézy. Rozhl Chir 77(1), 38-41.

7. Utíkal P. Implantace ePTFE interponátu. In: Bachleda P. (2001) Cévní náhrady v chirurgii arteriovenózních spojek k hemodialýze. PRODOS, Olomouc, 27-53.

8. Rueckman I, Ouriel K, Berry C, Hoffart A.(1991) The synthetic axillofemoral graft for hemodialysis access. ANNA Journal 18, 567-571.
Table 3. Reoperations of AF AVF.

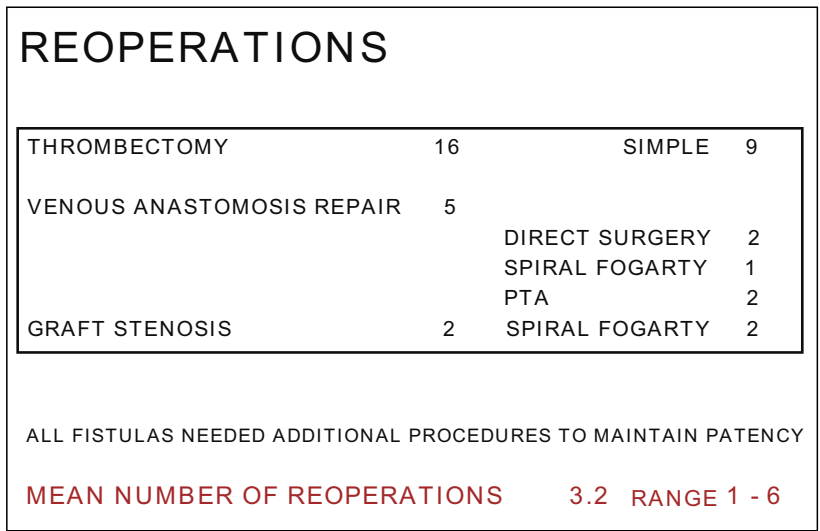

Table 4. Results of AF AVF.

\begin{tabular}{|c|c|}
\hline \multicolumn{2}{|c|}{$\begin{array}{l}\text { RESULTS } \\
\text { MORTALITY } \\
\text { NOBODY DIED PEROPERATIVELY OR LATER DUE TO FISTULA COMPLICATIONS }\end{array}$} \\
\hline \multicolumn{2}{|l|}{ ALL FISTULAS HAVE BEEN USED FOR DIALYSIS } \\
\hline THE MEAN DURATION OF USE & 26.6 MONTHS RANGE $6-52$ \\
\hline \multicolumn{2}{|l|}{ PATENCY } \\
\hline THE MEAN PRIMARY PATENCY TIME & 8.7 MONTHS RANGE $3-13$ \\
\hline CUMULATIVE FUNCTION & $100 \%$ \\
\hline THE LONGEST CUMULATIVE FUNCTION & $\begin{array}{l}\text { V } 52 \text { MONTHS } \\
\text { WITH NEED OF } 4 \text { REPAIRS }\end{array}$ \\
\hline
\end{tabular}

9. Clark DD, Albina JE, Chazan JA. (1990) Subclavian vein stenosis and thrombosis, a potentional serious complication in chronic hemodialysis patients. Am J Kidney Dis 15, 265-268.

10. Schwab SJ, Quarles DL, Middleton JP, Cohan RH, Saeed M, Dennis VW.(1988) Haemodialysis- associated subclavian vein stenosis. Kidney Int 33, 1156-1159.

11. Schillinger F, Schillinger D, Montagnac R, Milcent T. (1991) Post catheterization vein stenosis in haemodialysis: Comparative angiographic study of 50 subclavian and 50 internal jugular accesses. Nephrol Dial Transplant 6, 722-724.

12. Bennet W, Steward W. (1986) Subclavian vein thrombosis with single lumen venous catheters for hemodialysis. Clinical Nephrology 25, 25-54.

13. El-Nachef M, Rashad F. (1985) Occlusion of the subclavian vein: a complication of indwelling subclavian venous catheters for hemodialysis. Clinical Nephrology 24, 42-46.

14. Brescia MJ, Cimino JE, Appel K, Hurwich BJ. (1966) Chronic hemodialysis using venipuncture and surgically created arteriovenous fistula. N Engl J Med 275, 1089-1092.

15. Utíkal P, Bachleda P, Sekanina Z, Král V. (1996) Naše zkušenosti se zakládáním arteriovenózních spojek k dialýze s využitím cévního řečiště loketní jamky. Rozhl Chir 75, 83-87.

16. Smith VC, Hallet JW. (1983) Subclavian vein thrombosis during prolonged cathetrisation for parenteral nutrition : Early management and long term follow up. South Med J 76, 603-607.

17. Vesely TM, Hovsepian DM, Pilgrim TK. (1997) Upper extremity central venous obstruction in hemodialysis patients: Treatment with Wallstents. Radiology 204, 343-348.

18. Gray RJ, Horton KM, Dolmatch BL, Rundback JH, Anaise D, Aquino AO, Currier CB, Light JA, Sasaki TM. (1995) Use of Wallstents for hemodialysis access-related venous stenoses and 
occlusiopns untreatable with baloon angioplasty. Radiology 195 479-484.

19. Buriánková E, Köcher M, Bachleda P, Utíkal P, Kojecký Z, Černá M, Heřman M. (2003) Endovascular treatment of central venous stenoses in patients with dialysis shunts. Biomed Pap Med Fac Univ Palacky Olomouc, 147, 203-206.

20. Harder T, Christ F, Dewes W, Kronung G, Trubestein G.(1988) Phlebografie der oberen Extremität-Untersuchungstechnik, Indikationen und Ergebnisse. Roentgenblaetter 41, 273-279.

21. Hepp W, Aichinger CH. (1991) PTFE-Interponate in der intermittierenden Hämodialyse:Welche Faktoren haben Einfluss auf die primäre Funktionsdauer? Angio 1, 29-33.

22. Barlett ST, Schweitzer EJ. (1995) Early experience with a new ePTFE vascular prosthesis for hemodialysis. Am J Surg 170, 118124.

23. Posch L, Kafka-Ritsch R. PTFE Prosthese als Dialyseshunt- eigene Erfahrungen mit der Diastat Prosthese.In: Sommoggy S. (1998) Hämodialyse. Shuntchirurgie. Alois Erdl OHG, Trostberg, 119122.

24. Bachleda P, Utíkal P, Zadražil J, Köcher M. (1997) Méně časté komplikace po implantaci ePTFE protézy DIASTAT k dialýze. Mininvazivní terapie $I I, 50-51$.

25. Bachleda P. Cévní náhrady-ePTFE protézy. In: Bachleda P. (2001) Cévní náhrady v chirurgii arteriovenózních spojek k hemodialýze. PRODOS, Olomouc, 19-26.

26. Dapunt O, Feuerstein M, Rendl KH, Prenner K. (1987) Transluminal angioplasty versus conventional operation in the treatment of hemodialysis fistula stenosis: results from a 5 year study. Br J Surg 74, 1004-1005.

27. Kumpe DA, Cohen MAH, Durham JD. (1992) Treatment of failing and failed hemodialysis access sites: comparison of surgical treatment with thrombolysis/angioplasty. Seminars in Vascular Surgery $5,118-123$.

28. Bachleda P. ePTFE interponát v použití $\mathrm{k}$ hemodialýze-komplikace. In: Bachleda P. (2001) Cévní náhrady v chirurgii arteriovenózních spojek k hemodialýze. PRODOS, Olomouc, 54-86.

29. Roček M. Endovaskulární intervence při řešení komplikací arteriovenózních spojek k hemodialýze.In: Bachleda P. (2001) Cévní náhrady v chirurgii arteriovenózních spojek k hemodialýze. PRODOS, Olomouc, 89-108.

30. Bennett JD, Papadouris D, Rankin RN. (1997) Percutaneous inferior vena caval approach for long-term central venous access. J Vasc Intervent Radiol 8, 851-852.

31. Markowitz DG, Rosenblum DI, Newman JS, Garby KB. (1998) Translumbar inferior vena caval Tesio catheter for hemodialysis. J Vasc Intervent Radiol 9, 145-147.

32. Gokal R, Mallick NP. (1999) Peritoneal dialysis. Lancet 353,823828.

33. Lameire N, Peeters P, Vanholder R, Van Biesen W. (2006) Peritoneal dialysisi in Europe: an analysis of its rise and falls. Blood Purif 24, 107-114.

34. Brenner BM. (1996) The Kidney, 5th Edition, W.B.Saunders

35. Roubal P, Kříž V, Horváth R, Staffa R, Podlaha J, Kališ V, Leypold J, Gregor Z. (2000) Strategie a taktika sjednávání trvalého cévního prrístupu pro hemodialýzu a návrh organizačního zajištění této služby. Čes.Radiol., 54,122-124 